\title{
THE ROLE OF THE PUBLIC WORKS DEPARTMENT IN THE DEVELOPMENT AND ADMINISTRATION OF WATERWORKS IN KUALA LUMPUR, 1900-1941
}

\author{
Moo Hooi Ping \\ Joseph M. Fernando
}

\begin{abstract}
This article examines the role of the Public Works Department in the development and administration of waterworks in Kuala Lumpur between 1900 and 1941. It examines the early development of waterworks in Kuala Lumpur under British colonial rule and waterworks enactment that shaped the administration of water supply in the town. This research draws mainly from British colonial records and considers the major role played by the Public Works Department in introducing gravitational scheme to provide clean water supply. This article shows that the Public Works Department played a major role in the development and administration of waterworks in Kuala Lumpur, leading to the rapid growth and urbanization of the town.
\end{abstract}

\section{Introduction}

In the 1870s, Kuala Lumpur was under the administration of Yap Ah Loy. ${ }^{1}$ During his administration, Kuala Lumpur was visited by British officers and Malay rulers to build a good political relationship. W.T. Hornaday ${ }^{2}$, the American naturalist who visited Kuala Lumpur in 1878, described Kuala Lumpur as well-developed with houses covered with mud and attaps, a large town market selling a variety of fruits and vegetables and gambling places for entertainment. On the other hand, Frank Swettenham visited Kuala Lumpur in the 1880s and was impressed with the systematic settlements along the Klang River and Gombak River where people lived in different quarters with wide streets which were well-arranged. $\mathrm{He}$ acknowledged Kuala Lumpur as one of the best mining towns he had ever seen. The construction of roads took place to connect Ampang, Batu, Pudu and Petaling mines for the transportation of tin. Clearly, the economic condition in Kuala Lumpur was well-developed under the administration of Yap Ah Loy. As a result, he became one of the wealthy $\operatorname{men}^{3}$ in Kuala Lumpur.

In terms of social aspects, Kuala Lumpur was however not well-managed by Yap Ah Loy. The reason for this was the town hygiene ${ }^{4}$ not being a priority in his administration. This can be seen as rubbishes were not collected regularly. In addition, fires and floods of the Klang River destroyed the town. Many people were affected by epidemic diseases such as cholera, malaria and small pox. The town condition was thus unsatisfactory. In 1881, fire outbreak occurred twice and burnt down most of the houses and buildings. The floods of the Klang River washed away all the mud and the walls of houses. Most of the houses depended on buckets of water supply from the wells, which were polluted. ${ }^{5}$ Furthermore, the houses were poorly built and made of wood, covered by attaps with mud walls. It is obvious that there was a lack of town planning in Kuala Lumpur as there was no collection of rubbish, housing scheme, a clean water supply and prevention of fires and floods during the administration of Yap Ah Loy in the 1880s. ${ }^{6}$

In order to rebuild the town of Kuala Lumpur, Bloomfield Douglas, the British Resident of Selangor, instructed Daly ${ }^{7}$, the British officer from the Public Works and Survey Department to carry out geographical survey works in Kuala Lumpur for designation of schemes and estimates for town planning. Daly was assisted by Klyne who conducted surveys in the West 
part of Kuala Lumpur and around Yap Ah Loy's mines concession areas and his house of 12,000 areas within twelve months. ${ }^{8}$ The survey was still considered to be in the preliminary stage as Daly was also required to introduce proper mining regulations based on Chinese mines ownership and registration of land titles system. Meanwhile, Douglas also prepared some resolutions to improve the condition of Kuala Lumpur. One of the resolutions was the establishment of the Municipal Council. ${ }^{9}$ Douglas stated that this council required a supply of capital and therefore authorized to collect an assessment at the rate of five per cent on the annual value of houses and land within the municipality areas. The main duty of the Council was to make regulations for the improvement of the sanitary condition of the town. In addition, the Council was also responsible for the development of water supply, houses and buildings as well as roads, streets, markets, bridges and vehicles licence. Therefore, Douglas pointed out that with the establishment of the municipality in Kuala Lumpur, the town would be fully managed by the Council to improve the sanitary condition and the overall reconstruction of the Kuala Lumpur. This resolution was rejected by Frederick Weld, the Governor of the Straits Settlements, because it required a large amount of capital.

In 1890, the Sanitary Board ${ }^{10}$ of Kuala Lumpur was established to administer Kuala Lumpur. The Board's duties was to plan for the following works: cleaning and lighting the streets, administration of markets, metal streets, the construction of brick drains, widening roads and installation of signposts. The Board played an important role in encouraging the growth of township in Kuala Lumpur by implementing town-planning schemes. The Board acknowledged that water supply was the main factor that caused health problems in Kuala Lumpur. The reason for this was that most of the inhabitants obtained water from polluted river wells. The Sanitary Board of Kuala Lumpur immediately installed tanks at the markets and filled them with clean water brought by bullock carts from outlying sources. ${ }^{11}$ A clean water supply was important to improve the sanitary condition in Kuala Lumpur.

Many public works took place to improve sanitary condition in Kuala Lumpur. One of the most significant developments during this period was the development of the waterworks to provide clean water supply in Kuala Lumpur. Most of the houses depended on buckets of water obtained from wells which were greatly polluted. This led to the spread of water borne diseases among the townspeople. Frank Swettenham, the Resident of Selangor during that time, suggested water supply be provided through a gravitational scheme ${ }^{12}$ after his visit to the mining village along Gombak River and Klang River. ${ }^{13}$ This scheme was adopted widely in other British colonies such as Colombo, Singapore, Hong Kong and Bombay.

Bellamy, the State Engineer of Selangor, was assigned to conduct preliminary survey works on rainfall at Ampang, Kuala Lumpur, Klang River and Gombak River. Furthermore, Bellamy also conducted a survey at Pahang Road at a distance of about $71 / 4$ miles from Kuala Lumpur at a nominal head of 300 feet above the Market Bridge. Bellamy found that the water stream was very pure in quality with non-porous stone and could be used for the construction of the dam. Bellamy proposed a scheme to construct a reservoir with a capacity of 2.5 million gallons. As another alternative, Bellamy suggested the construction of new intakes and filter beds near Klang Gates and to be connected with the pipe lines at a distance of 5 miles with 9inches pipe between Pahang Road and Market Bridge. ${ }^{14}$ This was the preliminary survey works done by Bellamy to locate water sources for the construction of the dam.

Very few efforts have been attempted to study the development of waterworks in Kuala Lumpur and other important towns such as Taiping, Seremban and Ipoh. Gullick ${ }^{15}$ produced a number of writings of history of Kuala Lumpur and discussed briefly the development of Kuala Lumpur in general. Ahmad Kamal Ariffin ${ }^{16}$ examines the Sanitary Board of Kuala Lumpur as an important administrative body and acknowledged the Board's contribution to improve sanitary condition in Kuala Lumpur. On the other hand, Chai Hon Chan ${ }^{17}$ claims that the British government controlled water supply in order to avoid land disputes between the Chinese miners 
in the mining towns in Malaya. Most research works on Malaysian history tend to examine the origins and development of British colonial policies.

The article examines the development and administration of waterworks as a British colonial policy in Kuala Lumpur between 1900 and 1941. This research draws on primary sources such as Colonial Office records, Selangor Secretariat Files, Federal Department Annual Reports and Sanitary Board of Kuala Lumpur Annual Reports to examine the development of waterworks. This article is divided into three parts. The first part examines the early development of waterworks in Kuala Lumpur between 1890 and 1899. The second examines the development of waterworks between 1900 and 1941. The final part looks at the administration of waterworks.

The Public Works Department played a major in the development of waterworks especially in preparation of waterworks scheme and supervision of construction works. This article argues that the Public Works Department was an important administrative body in the development of colonial towns in Malaya by examining the development of waterworks in Kuala Lumpur. The development of good water supply in town depended on the engineer's professional advice and guidance. The construction of a town's water supply system took into consideration its population to provide adequate water supply for daily use and socio-economic activities. Waterworks were expanded considerably in the twentieth century. The Sanitary Board acted as an administrative body to impose and collect water assessment as a source of revenue in Kuala Lumpur.

\section{The Early Development of Waterworks in Kuala Lumpur, 1890-1899}

The early development of waterworks focuses on the development of waterworks scheme by H.C. Paxon ${ }^{18}$, the hydraulic Engineer involved in the construction of Ampang Impounding Reservoir carried out by the Public Works Department. This was to improve sanitary conditions in Kuala Lumpur due to poor town management. The Public Works Department carried out the construction works by contract-based system to ensure the construction works were completed on time. The early phase of the development of waterworks demonstrates the hydraulic engineer's expertise and guidance in the construction of Ampang Impounding Reservoir. Furthermore, the Public Works Department also introduced the public stand post system to provide water supply to government buildings and government quarters as the first set-up of the water supply system in Kuala Lumpur.

The Crown Agents in London sent Paxon to prepare waterworks scheme and develop the waterworks in Kuala Lumpur in 1890. He adopted the gravitational scheme to bring water supply to the town from Klang River and Gombak River. The construction of an impounding reservoir and a service reservoir were necessary as water storage facilities. Preliminary works were carried out with the construction of cooly line quarters, stores, and roads to the site of the reservoir. The cooly line consisted of $330^{19}$ people living near the reservoir site. In 1894, Paxon found a large quantity of vegetable impurities at the bottom of the reservoir. The reservoir had to be emptied and cleaned again to prevent the growth of the impurities. This was to avoid the pollution of the water supply. For safety purposes, Paxon proposed extra works to build a strong foundation at the bottom of the reservoir. These works consisted of puddling the bottom of the reservoir to provide protection and was made of dry rubble and gravel.

The proposal for the additional works ${ }^{20}$ was reviewed by James McRitchie, the Municipal Engineer, Singapore, and Major McCallum, the Colonial Engineer in London, who inspected works at the bottom of the reservoir. Both suggested to reduce the thickness at the bottom of the reservoir to reduce the risk of the formation of fissures. Paxon disagreed with this suggestion because it would make the bottom of the reservoir less water-tight. The proposal of the extra works suggested by Paxon was approved by the Government of Selangor after reviewed by McRitchie and McCallum. This shows that cross-referencing between the 
engineers solved the problem regarding the growth of impurities at the bottom of the reservoir. The impounding reservoir was completed with a capacity storage of 53,195,412 gallons situated five miles from Kuala Lumpur. In addition, the service reservoir was also completed with a capacity storage of 1,700,000 gallons, including bungalow main and service pipes with three days' supply that connected with a short length of 15-inches and 10-inches pipes. Other construction of works of dam, valve tower and masonry were also completed by the contractor, Messrs. Howarth, Erskine and Co. ${ }^{21}$

Paxon also supervised the construction of the channels. This was because the channels were important for future extension works. It formed a useful part of the construction of the waterworks. There were two channels constructed at Ampang. The first channel or Channel No. 1 was constructed at two miles in length sufficient to carry out the flood water. The first channel was covered by a brick arch with a distance of 378 feet along the hill to the dam. The second channel or Channel No. 2 was constructed with a distance of 1,600 feet together with a brick spill near the valve well. A gauge was fixed for daily measurement of the flow of water supply from the small reservoir. The pipe culvert carried water in order to avoid contamination of water supply. An open channel was also constructed two miles in length to provide an additional catchment area in order to increase water supply in the reservoir. ${ }^{22}$ It is clear that Paxon emphasized the construction of the channels to distribute water supply from the catchment area to the reservoir for storage purposes.

The Ampang Waterworks was completed with an expenditure of $\$ 570,000$ to provide water supply to a town with a population of 25,000 or 94 days of supply. The waterworks was still new. The distribution system was essential to provide water supply to all houses and buildings in Kuala Lumpur. There were two proposal suggested by Paxon and C.E. Spooner, the State Engineer from the Public Works Department in Selangor. Paxon proposed the tank system and meter system. The tank system was introduced to educate the public on the value of water supply. The tank was made of galvanized wrought iron or steel to be placed at convenient places for public uses. The fitting was made to prevent wastage which required high cost of maintenance. The tank will be supplied directly from the mains through large discharged pipes and filled three times a day by turncocks. The advantage of this tank system is that it prevented water wastage. The Waterworks staffs might have made adjustments on the fittings. In addition, the meter system was proposed for private supplies. In 1890s, the total number of houses in Kuala Lumpur was estimated to be about $1,100^{23}$ only.

On the other hand, Spooner proposed the public stand-post system to be placed about 100 yards throughout the town for public supply. The bungalows were installed with taps for water pressure adjustment. Spooner implemented the public stand-post system directly after the completion of Ampang Waterworks. This was because the tank system had a limited water supply of three times per day at 5 p.m., 10 a.m., and 3 p.m. by turncocks compared to the public stand-post which provided unlimited supply with the adjustments of water pressure. Spooner pointed out that the tank system would cause dissatisfactions among the consumers. The public stand-post ${ }^{24}$ was widely adopted in Kuala Lumpur. Clearly, the Public Works Department understood the importance of water supply in Kuala Lumpur to be implemented using the public stand-post system to provide unlimited water supply for domestic uses as well as for government buildings and quarters.

Defective pipes were a major problem in the distribution of water supply system. The pipes were essential for supplying water from reservoir to towns using public stand-posts. The bursting of pipes brought huge trouble to the Waterworks staffs and coolies with the repair works. Furthermore, the Inspector of Waterworks was required to make inspections of the fittings from time to time. $2,153^{25}$ bursts occurred in 1897 alone. It was followed by another $472^{26}$ bursts of public stand-posts. Brass taps were reportedly stolen and damaged. As a solution, fifty public stand-posts from affected areas were selected and tap-fitted with iron- 
clips and then screwed into the stand-posts. The results were shown to be satisfactory after a month trial.

The Public Works Department was also responsible to find out the suitable pipes for the Kuala Lumpur Waterworks to avoid the problem of bursting. The Public Works Department sent samples of the lead pipe and tin pipe to the Crown Agents in London to identify the quality and suitability of the pipes. The Crown Agents consulted Henry Wakefield, the Birmingham Agents, Chadwick, the Consulting Engineer and Blackmore from Messrs. V. \& R., the pipes manufacturer. The lead pipe made of pure block tin and pure lead was supplied by Messrs. V. $\& \mathrm{R}$ for the Kuala Lumpur Waterworks since 1893. ${ }^{27}$ As a result, the Crown Agents were unable to identify specific measures to avoid defective pipe.

Meanwhile, in Kuala Lumpur, the Public Works Department together with the Sanitary Board of Kuala Lumpur conducted several tests to identify the reasons for defective pipes. Spooner, the State Engineer from the Public Works Department tested the strength of lead encased tin lined pipes by placing the pipes to the 3-inch main at the Railway Wagoon Work. The Federated Engineering and Co. tested the gauge and found the right pressure when the gauge was attached to the hydrant. E.L. Grove, the Acting Sanitary Board Engineer together with G. H. Fox, the Assistant Engineer and O' Hara, the Inspector of Kuala Lumpur Waterworks, tested the bursting rate of the pipes by gauging of $85 \mathrm{lbs}$. pre-pressure with rapid water pressure for five days. It was found out that the pipes burst on the third day of the test ${ }^{28}$. From the result of the tests, Spooner found out that the pipes from the Crown Agents in London was manufactured in poor quality. Clearly, the Public Works Department successfully found the reason for defective of the pipes in the Kuala Lumpur Waterworks.

The early phase of the development of waterworks demonstrated Paxon's advice and guidance in the proposal to make Ampang Impounding Reservoir water-tight. The crossreferencing made between the engineers shows that engineering expertise was readily available to solve technical problems in the development of waterworks scheme and its construction works between Kuala Lumpur and Singapore. Paxon's advice and guidance contributed to the construction of the Ampang Impounding Reservoir. On the other hand, the Public Works Department played its role in the distribution of staff and labour for the construction works at Ampang Impounding Reservoir under the contract-based system. The contractors were appointed by the Public Works Department to carry out the construction works at Ampang. This system was adopted to save time and cost. In addition, the purchase of waterwork materials from the Crown Agents in London was another responsibility of the Public Works Department (by submitting indents or order of purchase). The accuracy of the waterworks scheme and estimates were essential for the approval of funds from the Government of Selangor.

\section{The Development of Waterworks in Kuala Lumpur, 1900-1920}

The development of waterworks took place very rapidly in the first two decade in Kuala Lumpur. This was primarily due to the growing population in the city. In this regard, the Public Works Department carried out extension works at Ampang and WeldHill to provide additional water supply. Unfortunately, dry spell and drought caused water scarcity between 1900 and $1908^{29}$. It was important for the Public Works Department to locate new sites for water storage for supply and future extension works. The extension works expanded considerably between 1900 and 1920, leading to an increased in water storage in Kuala Lumpur. The Public Works Department played a major role in the extension works to increase water catchment area to avoid disruption of water supply.

In 1900, it has been found that the volume of water in the reservoir amounted $16.5^{30}$ million gallons, meaning water supply was to be very limited. Under this circumstance, the Public Works Department prepared waterworks extension scheme to increase water in Kuala 
Lumpur. H.C. Belfield, the British Resident of Selangor pointed out the need for an effective waterworks scheme to executed in order to solve disruption of water supply. For Belfield, the waterworks scheme had to consider the following matters: daily consumption of water by the public; sufficiency of the reservoirs and catchment areas to meet daily demand and proposals for improving catchment areas; and lastly supervision and restriction of public water consumption. In addition, Belfield also considered the adoption of public standpipes and law enforcement to authorize Inspectors to control private supplies by surprise visits to avoid wastage. It is clear that the British Resident of Selangor was concerned with the sufficiency of water supply in Kuala Lumpur through the development of waterworks scheme. ${ }^{31}$

The Sanitary Board also played an important part by proposing to increase the quantity of water supply by extending the catchment area around the impounding reservoir at Ampang. Meanwhile, O' Hara, the Inspector of Waterworks, suggested to supply water from Lake Sydney $^{32}$ into the service reservoir as an alternative source with the installation of dipper fountain to replace water cocks to avoid wastage. A special provision of $\$ 25,500^{33}$ was allocated for the survey works at Lake Sydney. Water samples from Lake Sydney were reportedly satisfactory to be used as supplementary supply to the Ampang Impounding Reservoir. It is important to note that the Sanitary Board contributed the idea of the enlarging the catchment area at Ampang and providing supplementary supply from Lake Sydney. These helped the Public Works Department to prepare the waterworks scheme for extension works at Ampang.

The Public Works Department prepared two extension work schemes. The first scheme was the original proposal of the extension of catchment area with the construction of a tunnel of 1,900 feet in length. Another scheme was for high level supply with the construction of a pipe line from the upper branches of the Ampang River. ${ }^{34}$ These two extension work schemes were adopted to increase the catchment area at Ampang. In 1902, the extension works began with an expenditure of $\$ 57,500^{35}$ with the construction of headwork and pipe line. This also included the extension of the catchment area of 2.670 acres for an additional water storage of five million cubic feet. A bypass was constructed at the impounding reservoir to examine if the dam could be emptied easily. There were 38 dipper fountains installed and existing venturemeters were fixed and repaired on the mains from the service reservoir. However, the condition of the service reservoir remained unsatisfactory. In addition, there were six additional mains laid for the supply to suburban areas. Private supplies were closed for some time during the extension work. Following the completion of the first extension work, water supply at the Ampang Impounding Reservoir was thereafter well-maintained.

In 1905, the Public Works Department proposed another scheme to increase the capacity of water supply by exhausting water from the Electric Turbo Generators at Ulu Gombak $^{36}$. The purpose of the scheme was to provide water supply for a town population of 66,000 with a maximum expenditure of $\$ 500,000$. This scheme was considered suitable for tropical countries to provide adequate water storage in the new service reservoir for low-level Supply in Kuala Lumpur. This scheme was revised and improvised by R.O.N. Anderson, the Director of Public Works, for large extension works ${ }^{37}$ in Kuala Lumpur. Anderson's scheme was subsequently revised by Peirce, the Municipal Engineer in Singapore. A cross-referencing was made between Anderson and Peirce to carry out a large extension work in Kuala Lumpur. Peirce introduced the new design for the dam known based on a 'continuous flow' system that had already been adopted in Penang, Calcutta, Meerut and Hankow. This flow system was used to ensure water supply flow in the settling tanks within 36 hours and had the capacity to hold 1.6 million gallons of water. ${ }^{38}$

The new dam design was introduced because existing dam in Kuala Lumpur was wrongly built causing leakages through fissures. For Peirce, it was the design that caused the leakage and not the fissures per se. He also emphasized the use of steel pipes at the Ampang 
pipe lines to avoid the risk of interruptions and lap-welded steel pipe instead of spirally riveted pipe $^{39}$ to be used in the new pipe lines. This scheme was adopted in the extension work at WeldHill with an estimate of $\$ 564,000^{40}$ for the construction of a low-level service reservoir. Another provision of $\$ 700,000^{41}$ for large extension works and purchase of the waterworks materials by an indent to Crown Agents for pipes and fittings. The WeldHill supply consisted of an impounding reservoir at Ampang River, a settling basin, three sand filters and a service reservoir. Overall, the construction a new reservoir at WeldHill was satisfactory and watertight.

J.E. Bach ${ }^{42}$, the Executive Engineer of Waterworks, suggested another extension work scheme at the Sleh River to provide ample water supply for the next ten years with the construction of three settling ponds, channels, filters and a main pipeline. The Public Works Department addressed the extension work at Sleh River as unnecessary because the existing waterworks were deemed sufficient to sustain water supply in the town. Moreover, wastage of water supply frequently occurred at bungalow mains and government quarters. Therefore, the Public Works Department focused on the repair and installation works of the new 10-inch pipe at bungalow main to improve water supply. The plan of the extension work at Sleh River was under consideration as the repair works took place to improve existing water distribution system.

The development of waterworks between 1900 and 1920 demonstrates the role of the Public Works Department to plan and execute extension works to provide additional water supply and improve water distribution in Kuala Lumpur. The improvement works took place with the installation of new mains and pipelines throughout the town. By doing so, the Sanitary Board provided assistance to the Public Works Department to locate new water supply at Lake Sydney and Sleh River for future extension. The Public Works Department constructed new service reservoirs at Ampang and Weld Hill to provide additional water supply for domestic purposes. In the middle phase of the development waterworks improved gradually with the supervision of the Public Works Department in extension and improvement.

\section{The Development of Waterworks, 1921-1941}

Large extension to the waterworks took place between 1921 and 1941. This was because the water treatment system that was introduced to provide clean water supply by chlorination or chloronomes. It was one of the significant developments of the water supply system to provide pure water supply for all in Kuala Lumpur. The Public Works Department continued the extension of Kuala Lumpur Waterworks Extension Scheme for improvement works at Maxwell Hill Reservoir and the construction of new supply at Sleh River or also known as the Kuala Sleh Supply.

The improvement works took place at Maxwell Hill Reservoir in 1923. The Maxwell Hill Reservoir was reconstructed with an expenditure of $\$ 51,485$ due to serious leakage ${ }^{43}$. The Maxwell Hill Reservoir was one of the important reservoirs that had a capacity storage of quarter million gallons at a height of 315 feet. In 1926, there was a suggestion made by the Public Works Department that the Maxwell Hill Reservoir should be gazetted as waterworks reserve in Kuala Lumpur. However, the condition of the reservoir was unsatisfactory due to leakage. In the 1930s, the Maxwell Hill Reservoir improvement works took place successfully by increasing the capacity of water storage up to 120 million gallons. ${ }^{44}$ It is clear that the Public Works Department took an initiative to improve the water storage system at Maxwell Hill Reservoir.

In this phase of the development of waterworks, the Sleh River Supply was the final extension works took place by the Public Works Department to provide water supply for a town population of 100,000. It was the most modern water supply system in Kuala Lumpur with specially designed sedimentation tank and filtration system. The extension work scheme 
was prepared by the Hydraulic Branch. Initially, W.A. Wilkinson, the State Engineer proposed the scheme with an estimate of $\$ 607,000^{45}$ by conducting preliminary survey at Klang Gate. Wilkinson suggested two major improvement works at 10-inch main in Kuala Lumpur and the new main at Ampang to Weld Hill Reservoir.

Meanwhile, E.L. Bennett, the Chief Hydraulic Engineer revised Wilkinson's scheme. Bennett prepared an extension scheme with an estimate of $\$ 2.2^{46}$ million including Rifle Range as a new site for construction of service reservoir. For Bennett, the extension works at Sleh River and Klang River were insufficient due to the distance between both streams was far to each other for water supply to flow into the settling tanks. As an alternative, the construction of a service reservoir was necessary at Rifle Range to discharge 3.6 million gallons of water per day by a 24-inch main for extension works at Sleh River.

The Sleh River extension scheme was approved and an indent of $\$ 968,800$ sent to Crown Agents in London to purchase pipes and other waterworks materials. The extension works at Sleh River consisted of the construction of an impounding reservoir across the valley of the river of Kuala Sleh and the construction of a service reservoir at Sentul Hill. The service reservoir at Sentul Hill was known as the largest tank in the Federated Malay States and had a capacity storage of six million gallons. This reservoir also supplemented existing service reservoirs in Kuala Lumpur. This was a large extension works requiring a large labour force of 600 to 700 men with an expenditure of $\$ 2,025,105 .{ }^{47}$ The reservoir was successfully completed with water-tight in 1928. The large extension works at Maxwell Hill Reservoir and Sentul Hill Reservoir were carried out successfully by the Public Works Department. The Sleh River extension scheme was the largest and modern waterworks in Kuala Lumpur.

The water treatment system ${ }^{48}$ using choline was introduced to provide pure water supply. The experiments took place at Ampang Intake using gaseous chlorine plant to obtain drinking water. The result was satisfactory with high standard of purity. Two chlorine plants were purchased from the Crown Agents and were installed at Sleh Hill Reservoir and Maxwell Hill Reservoir. As a result, piped-water supply was mostly filtered and chlorinated in Kuala Lumpur.

The final phase of development of waterworks ended with the large extension works at Sleh River. There were three separate water sources: High Level Supply at Ampang, Low Level Supply at Ampang, and the Kuala Sleh Supply. There were also three service reservoirs which were the Weld Hill Reservoir, Maxwell Hill Reservoir and Sentul Hill Reservoir. The Public Works Department successfully constructed three impounding reservoirs and three service reservoirs to provide adequate water supply for a town population of 138,500 in 1939 . The Public Works Department worked closely with the Institute of Medical Research to examine the quality and purity of water supply. The examination of water purity system adopted in Kuala Lumpur had similar standard of purity authorized by the London Metropolitan Water Board $^{49}$. This was to ensure the safety of water consumption in Kuala Lumpur.

The Public Works Department played a major role in the development of waterworks in Kuala Lumpur mainly because of the growth of the town population between 1900 and 1941 . It was essential for the Public Works Department to plan and supervise the extension works and improvement works to meet the needs of the town. In fact, the town population increased from 25,000 in $1890^{50}$ to 138,500 in $1939 .{ }^{51}$ The water supply system depended on the engineer's guideline and expertise to plan and prepare waterworks scheme and its extension works scheme. The Public Works Department took this opportunity to extend the development of waterworks to the suburban areas such as Klang, Sungai Besi, Sungai Buloh and Kepong. It shows that the waterworks developed continuously from time to time. Furthermore, the department also played another important role in the administration of waterworks in connection with the distribution of water supply under control by the State Engineer of the 
Public Works Department. Therefore, the development of waterworks in Kuala Lumpur included construction and administration works.

In 1896, the Sanitary Board of Kuala Lumpur took over the administration of waterworks under Regulation of No. $61896^{52}$ to impose water rate and assessment. In 1909, the Public Works Department took over the administration of waterworks under the Waterworks Enactment of 1909 to supply water to consumers. Under the administration of the Public Works Department, water supply was improved to meet the needs of the town population. It appears that the Public Works Department took control of the distribution of water supply in Kuala Lumpur after the first extension works were completed at Ampang. This was following limited water supply due to dry season and draught between 1900 and 1908. The Public Works Department continued to improve water supply by working closely with other departments especially the Sanitary Board of Kuala Lumpur and Institute of Medical Research.

\section{The Administration of Waterworks in Kuala Lumpur, 1900-1941}

The Public Works Department played a role as an administrative body to provide water services in Kuala Lumpur by examining water regulation and enactments. These include Regulation of No. 6 in 1896, the Waterworks Enactment 1909 and the Water Supply Enactment of 1926. The Regulation of No. 6 in 1896 was the establishment of waterworks administration to impose water rate and assessment. On the other hand, the Waterworks Enactment 1909 and the Water Supply Enactment of 1926 emphasized water supply to the public by the installation of pipes and fittings. Furthermore, the role of the State Engineer was important to facilitate water services and impose penalties to the public throughout the twentieth century. The Public Works Department received assistance from the Sanitary Board to provide adequate water supply for domestic purposes. The water enactment was important to regulate water rate and to protect the water supply system in Kuala Lumpur as part of British colonial administration.

The Waterworks Enactment of $1909^{53}$ emphasized the role of the State Engineer who played a very important part in the administration of waterworks in Kuala Lumpur. Under the waterworks enactment, all application for new supplies must be submitted to the State Engineer for approval. The Public Works Department was responsible with new supplies and the laying of pipes and fittings ${ }^{54}$. Furthermore, the Waterworks Department of the Sanitary Board Kuala Lumpur was placed under the supervision of the State Engineer for all repair and maintenance works of private supplies in the town. Water services improved as all applicants were required to pay the actual cost of the materials supplied by the State Engineer. Another additional 10\% of labour fees ${ }^{55}$ from the Public Works Department was also imposed to the applicants for connection of new supplies.

The role of the State Engineer was important in the event of damages of waterworks caused by the public. ${ }^{56}$ The State Engineer may impose penalties to the public who caused any damages to the waterworks. It can be seen in the waste of water at government quarters. The penalties ${ }^{57}$ were imposed in order to control water supplies. The State Engineer was authorized to disconnect water supplies immediately to the consumers if water wastage occurred. Several cases reported show that the Waterworks Enactment of 1909 had authorized the State Engineer to protect the waterworks. In 1905, there were three reported cases of wastage by the Assistant Inspector of Waterworks who found the water was running wastefully at Damansara Road, High Street and the stand-pipe in the kitchen at the High Street Barracks was left open allnight. ${ }^{58}$ In 1914, the water wastage was reported at Low Level Supply at Ampang with an average about $3.5^{59}$ million gallons of water daily ran to waste. In 1915, four men were found bathing in the Ampang High Level Supply Reservoir. The Sanitary Board of Kuala Lumpur took immediate action with an approval of the State Engineer by imposing fine not exceeding $\$ 50$ and issuing a warning notice to the public against polluting the waterworks. ${ }^{60}$ 
The amendment of waterworks enactment made under the Water Supply Enactment of $1926^{61}$ placed all the management of waterworks under the control of the State Engineer. The State Engineer dealt with the matters regarding damages and pollution of waterworks caused by the public. The Water Supply Enactment of 1926 was standardized in the Malay States. There were additional four clauses regarding penalties to be imposed on anyone who caused damages on the waterworks: fine not exceeding $\$ 500$ or imprisonment not exceeding six months. These clauses were designed to protect the waterworks. ${ }^{62}$ These four additional clauses reflect the problems confronting waterworks in Kuala Lumpur. The State Engineer was required to manage waterworks in the Malay States to protect water sources for the socioeconomic activities in Kuala Lumpur and other suburban areas.

The water enactments was improved to distribute and to control water supplies in the town. However, the Public Works Department faced difficulties in the management of the meters and the collection of the water rates. These problems were solved with better meters purchased from the Crown Agents. The meter system improved the billing system in Kuala Lumpur. This was because the Sanitary Board faced difficulties in collecting water rate and assessment from private supplies. Meters were important for readings to issue bills for water charges. It was also used to record water consumption for both domestic and trade supplies. Furthermore, the Executive Engineer was able to obtain reliable and more accurate readings ${ }^{63}$ of water consumption. This system also created a uniform collection of water charges in the Malay States. Even though, the cost of repairing, replacement and maintenance (under the management of the Public Works Department) were high. To improve record of water consumption, the Deacon ${ }^{64}$ water meter was used with reference to Great Britain where it worked well and operated effectively.

The Public Works Department faced defective meters problem that caused reading errors and inaccurate water charges. Between the 1910s and 1920s, the Public Works Department received complaints from the public regarding meters not functioning well with glaring reading errors. In 1927, Sidney Morgan from Wilde \& Co. Ltd. made two complaints regarding the water supply at Federal Hill. The first complaint stated that the meter was removed by subordinates from the Public Works Department for some time without notice or any new replacement. Morgan addressed that there was no notice given from the Sanitary Board of Kuala Lumpur and the Public Works Department for the inspection. The second complaint stated Morgan's disappointment to the Sanitary Board of Kuala Lumpur and that the Public Works Department failed to provide good water supply services. ${ }^{65}$ In fact, the meters required high maintenance cost, repair cost and replacement, all under the management of the Public Works Department. By contrast, in Great Britain, meters were not used in metropolitan areas such as Glasgow, Liverpool, Manchester and Bradford. ${ }^{66}$ This was because water supplies were managed by private water companies. In the context of Kuala Lumpur, the meters were important to obtain reliable data of water consumption for records and billing purposes.

To overcome defective meter problem, the tap system of fixed rate, supplied by the Public Works Department, was introduced as an alternative for those with high water consumption with taps. There were nine class of quarters charged with a range from $\$ 3$ to $\$ 20 .{ }^{67}$ The tap system was only implemented for public supplies in accordance with the Waterworks Enactment of 1909 and the Water Supply Enactment of 1926. Another solution was the meters charged accordingly based on the size of the meter. There were seven different sizes of meter with different charges from $1 / 2$-inch for $\$ 4$ to 3-inches for $\$ 50^{68}$ respectively. The rent for meters was required to be paid every six month in advance. The examination of meter was made by official write-in.

A deposit receipt of $\$ 5$ signed by the Chairman of the Sanitary Board of Secretary of the Sanitary Board would be returned to the owner. The State Engineer conducted the examination on meters, and if it was found out of order and required for renewal or repair, the 
deposit of the examination of meter would be refunded to the owner and repair works carried out immediately. This procedure was adopted to pay the coolies under the Public Works Department accounts for the distribution of staffs and labourers for maintenance works. As a result, the Waterworks Department worked effectively with the appointments of European meter readers to facilitate the private supplies. Moreover, the Waterworks Department was also placed under the supervision of the State Engineer who supervised the maintenance of meters throughout Kuala Lumpur.

The Public Works Department improved the water consumption in Kuala Lumpur throughout the twentieth century with extension works and administration works. The Executive Engineer of Sanitary Board collected information on annual population and annual water consumption to identify the quantity of water supply required for extension works. The water consumption increased mainly due to an increase in town population. Between 1900 and 1908 , the water consumption was low and very limited due to dry spell and drought with an average daily consumption of less than 200 million gallons for a town population of $32,381 .^{69}$ The water supply greatly affected private supplies. In 1904, there were only $81^{70}$ new supplies connected consisting of 24 trade supplies, 31 shop houses and 26 private houses supplied by meter. The total number of supplies were very limited in Kuala Lumpur. In addition, water supply was only given for public supplies in eight areas in Bukit Nanas, Weld Road, Treacher Road, Birch Road, Vagrant Ward, General Hospital, West Hill, Railways Quarters and Brickfield Road. $^{71}$

Between 1910 and 1920, water consumption improved with repair works due to leakage at the service reservoir. The water consumption increased drastically from $114.5^{72}$ million gallons to $895^{73}$ million gallons respectively. The town population also increased from $46,718^{74}$ in 1911 to $80,424^{75}$ in 1920 . This shows that the water consumption increased gradually with the increase in town population. Furthermore, water services also improved with the supply of piped-water obtained from the headworks to all the main roads. In 1915 , there were $571^{76}$ new supplies connected in Kuala Lumpur, the highest new supplies given to the public in town. The water services improved drastically through the Waterworks Enactment of 1909 which facilatated the Public Works Department in the laying of pipes and fittings for private supplies with proper legislation and guidelines.

The water services improved continuously through water supply enactment and water treatment system in 1930. The distribution of water supply in town became systematic under the Water Supply Enactment of 1926. This enactment was standardized throughout the Malay States. This enactment was passed after the completion of the Kuala Sleh Supply as the largest water storage tank in the Federated Malay States to provide additional water supply in Kuala Lumpur. The water consumption improved gradually in Kuala Lumpur with the Kuala Sleh Supply. Furthermore, the introduction of water treatment system successfully produced clean drinking water using chlorine, increasing water consumption to $2,053,186,750^{77}$ gallons for a town population of $111,738^{78}$ in 1930 . This figure was considered the highest consumption in the 1930s. The Water Supply Enactment of 1932 was passed to improve water payment system by agreement renewable every year for all standardized supplies. This made the application of water supply easier and time-saving.

The waterworks enactment recognized the Public Works Department as an important administrative body to provide water supply in Kuala Lumpur. At the same time, it also improved water services especially in the installation of pipes and fittings and meter rent for billing purposes. This enactment was enacted by adopting the water supply administrative system of the Straits Settlements and London. For example, the Water Supply Enactment of 1926 was enacted with the combination of the Straits Settlements Municipal Ordinance 135, Colonial Municipal Ordinance, Regulation of No. 6 of 1896 and the Waterworks Enactment of 1909. This enactment was amended to provide better water services to the inhabitants of Kuala 
Lumpur. Water services improved gradually with the increase of water consumption throughout the twentieth century.

Overall, the Public Works Department controlled the distribution of water supply to the public effectively under the Waterworks Enactment of 1909 and the Water Supply Enactment of 1926. This was due the population increase between 1890 and 1941. The Kuala Lumpur Waterworks was considered effective because it fulfilled the daily needs of the town population.

\section{Conclusion}

The development of Kuala Lumpur was not only based on its political-economic landscape as an important mining town of the Federated Malay States. The waterworks contributed significant improvement to the infrastructural and socioeconomic development of Kuala Lumpur. This article suggests that the Public Works Department contributed to the development and administration of waterworks. It played a major role in the administration of waterworks especially in adopting a piped-water supply compared to the previous well-watered supply. Another significant change was the introduction of water treatment system to produce clean water supply using chlorine. These changes improved sanitary condition in the town and urban living by providing. Between 1900 and 1941, the Public Works Department successfully built three main water supply system in Kuala Lumpur which were the low-level supply at Ampang, the high-level supply at Ampang and Kuala Sleh intake supply. In addition, there were three service reservoirs successfully built to provide additional water supply which were the Maxwell Hill Reservoir, Weld Hill Reservoir and Sentul Hill Reservoir.

The Public Works Department also played an important role in the development of waterworks schemes in Kuala Lumpur to provide and control additional water supply for domestic purposes. It prepared and revised the waterworks schemes for extension works. Cross-referencing was made to the Municipality in Singapore and London to obtain better understanding of the schemes. Professional expertise was aksi easily available particularly the engineers who were able to offers solutions to solve technical problems pertaining to the waterworks. The extension works scheme was prepared by the State Engineer and submitted to the Director of Public Works and to Municipal Engineer in Singapore for approval. Although it took a long time for the approval, the extension works were carried out successfully with the funds from the Government of Selangor, which built the largest tank in the Federated Malay States.

In administrative aspects, Waterworks Enactment of 1909 and the Water Supply Enactment of 1926 made the Public Works Department an important administrative body to develop and to control the water supply in Kuala Lumpur. The Department was responsible in the installation of pipes and fittings which were important for new connection to improve the distribution of water supply in Kuala Lumpur. As a result, water consumption increased under the supervision of the Public Works Department. The water enactments also empowered the State Engineer to impose penalties to the public who caused damages to the waterworks in Kuala Lumpur. In addition, the State Engineer was also authorized to give approval for the application of new water supply connection in Kuala Lumpur and Selangor. This shows that the State Engineer was responsible in the distribution of water supply in Kuala Lumpur between 1900 and 1941. As a result, this made water supply easy available and accessible especially with the installation of pipes and fittings to all houses and buildings in the town.

The waterworks was a part of the British policy to provide safety and comfort to the public through an effective water supply system. The development of the Kuala Lumpur Waterworks contributed to the growth of the town. This article provides a dimension on how British colonial policies shaped Kuala Lumpur by examining the development and administration of waterworks as an important infrastructure to facilitate the socio-economic 
activities of the town. It is also essential to address the Public Works Department as an administrative body as it contributed to the growth of township, specifically Kuala Lumpur. These findings represent a gap in the study of British colonial policies in Kuala Lumpur.

\section{Appendices}

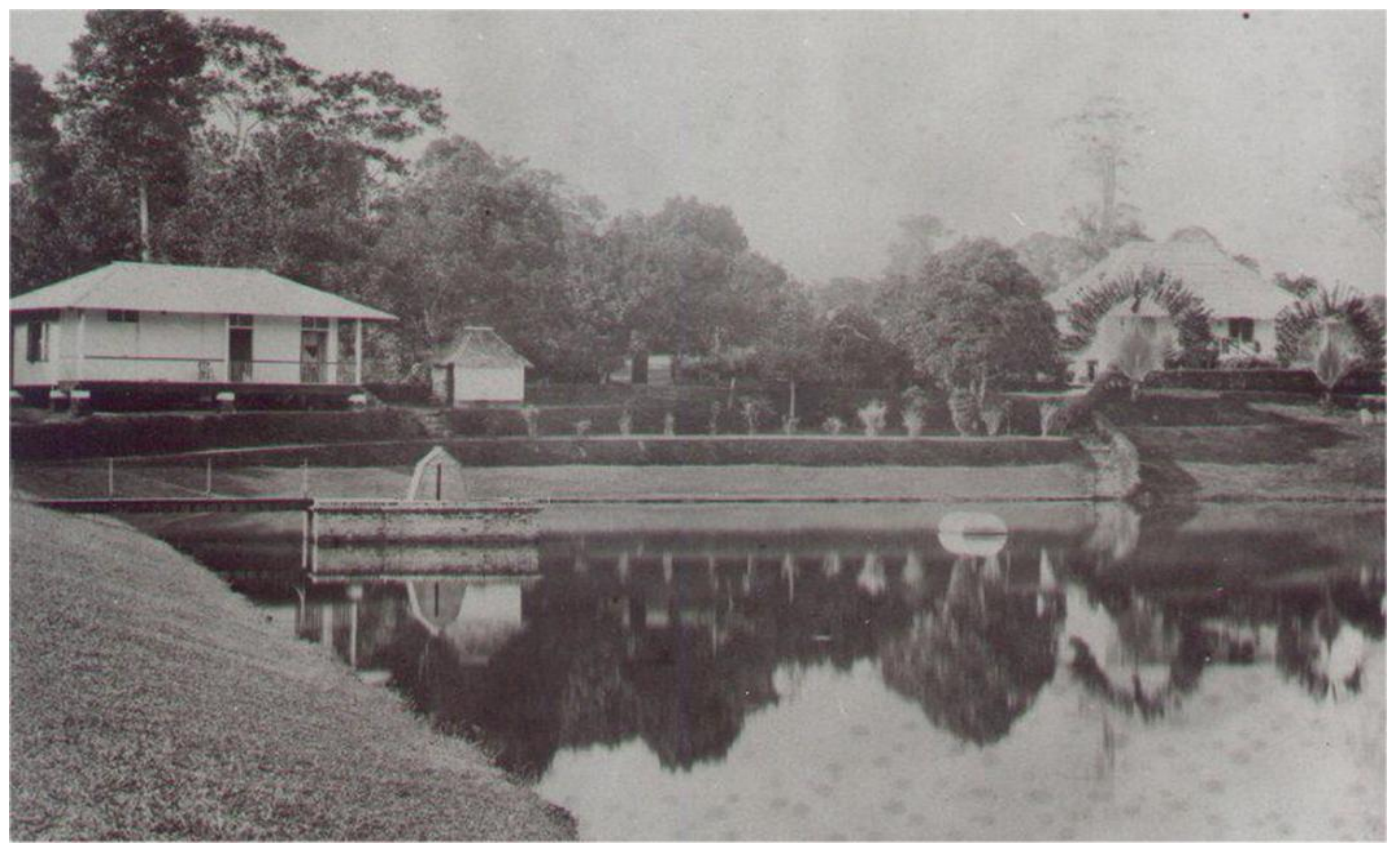

Source: Waterworks, Kuala Lumpur, National Archives of Malaysia
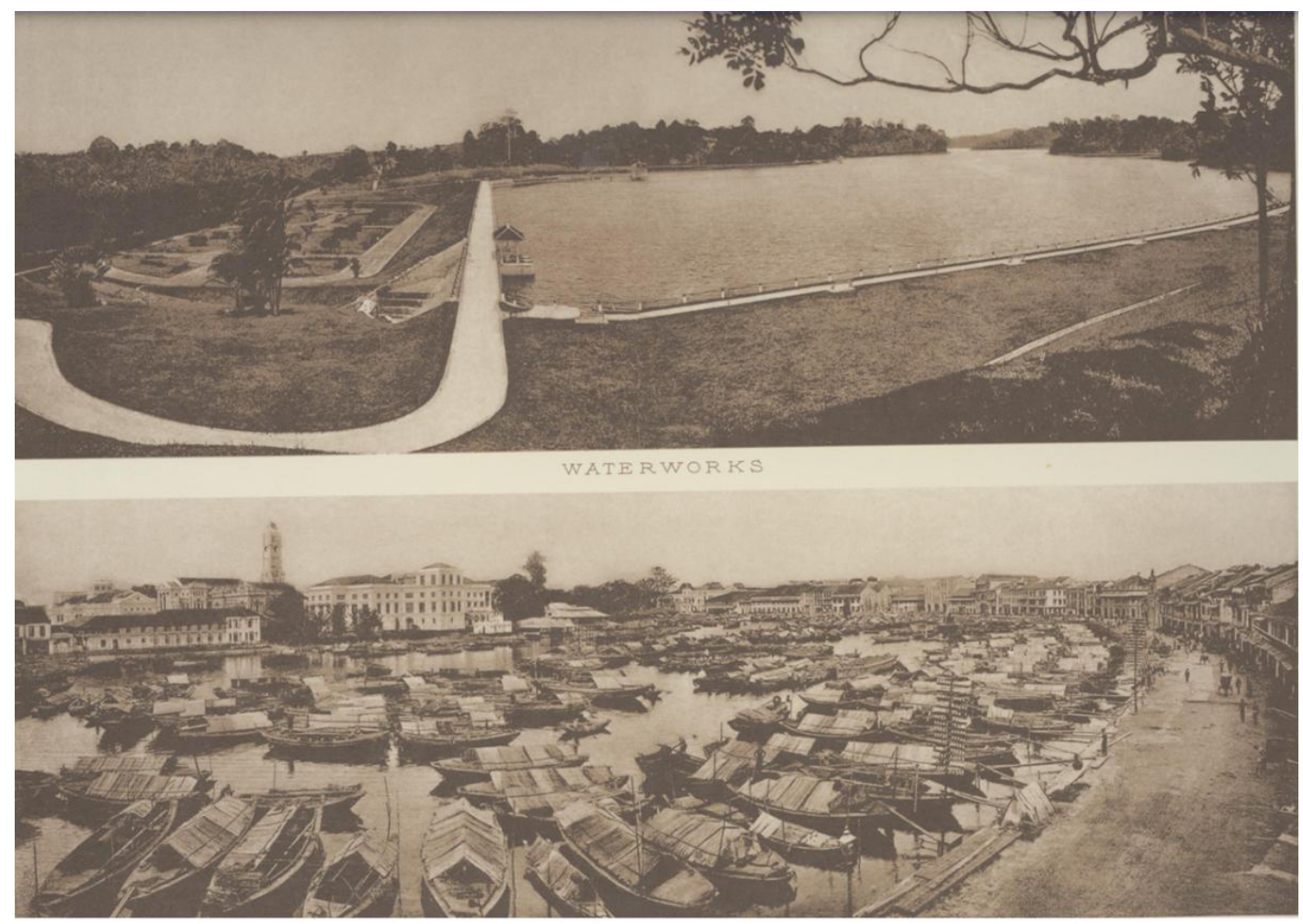
Source: Waterworks, Kuala Lumpur, National Archives of Malaysia

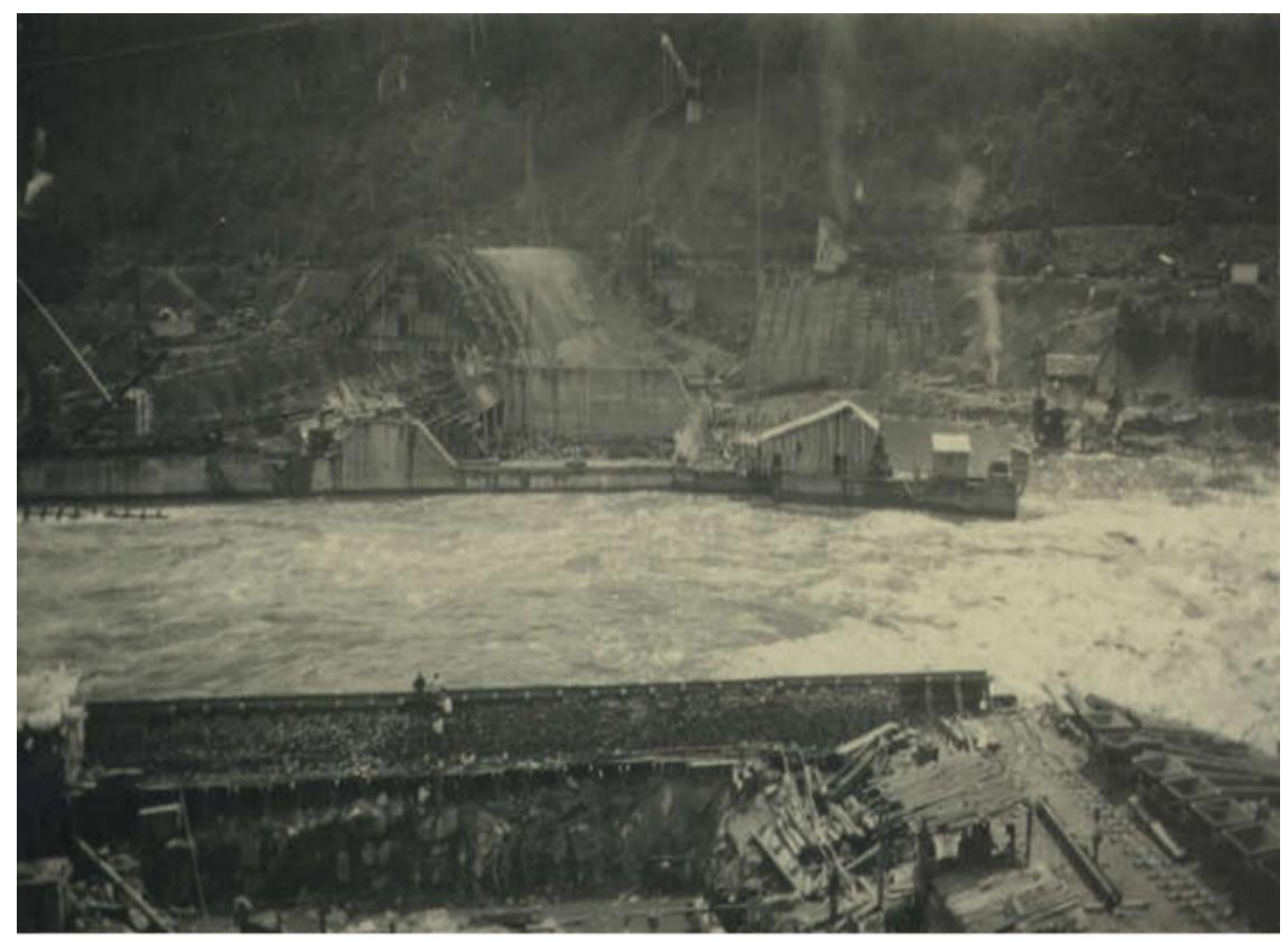

Source: Waterworks, Kuala Lumpur, National Archives of Malaysia

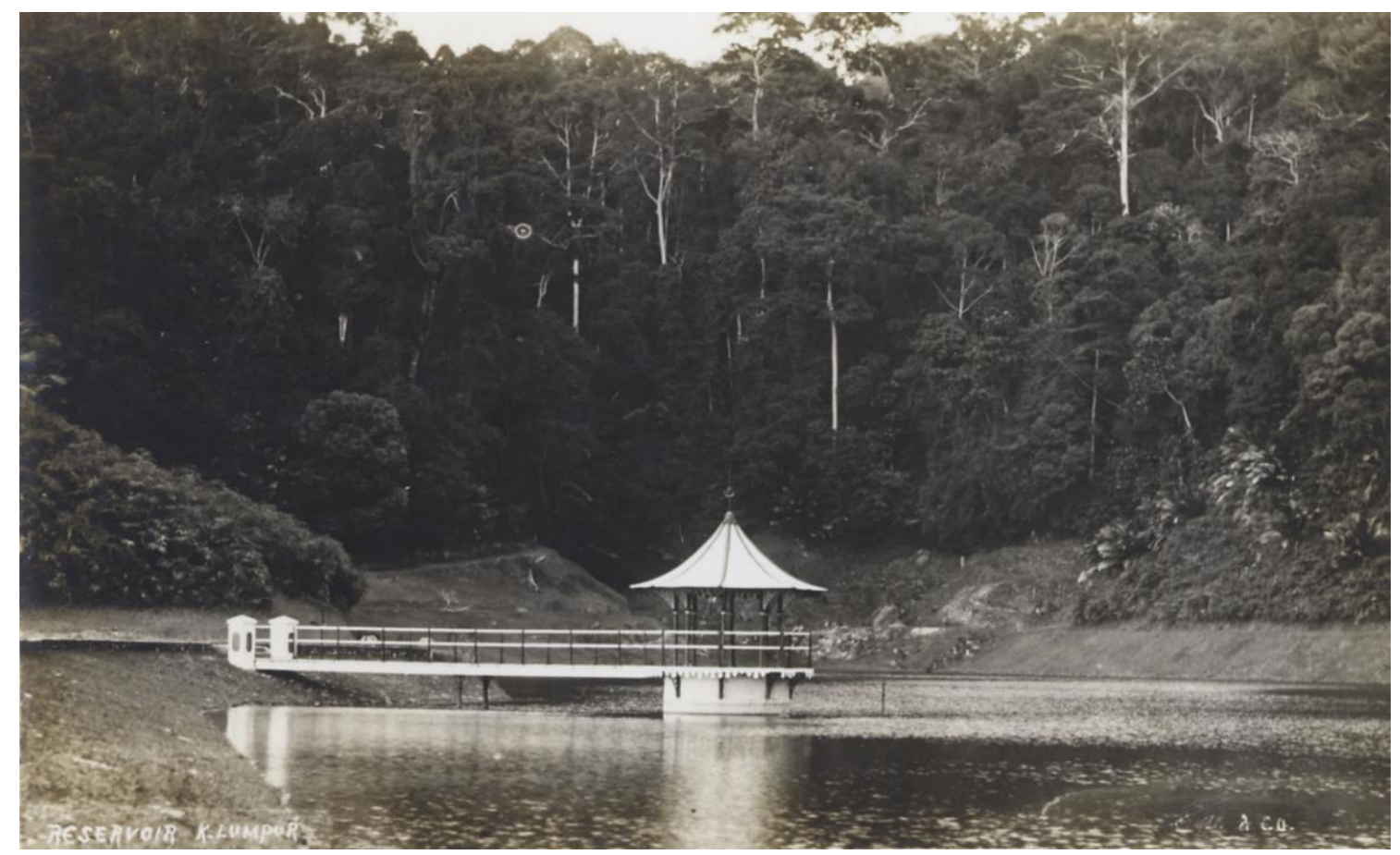

Source: Waterworks, Kuala Lumpur, National Archives of Malaysia 


\section{Notes}

${ }^{1}$ C.K., Yap Ah Loi, Selangor Journal, Volume 2, 1893, pp. 184-185.

${ }^{2}$ W. T. Hornaday, Two Years in the Jungle: The Experiences of a Hunter and Naturalist in India, Ceylon, the Malay Peninsula and Borneo, New York: Charles Scribner's Sons, 1885, pp. 315-316.

${ }^{3}$ In 1886, the Kapitan China in Kuala Lumpur controlled 30 per cent of the total tin input in Selangor. Refer to J.G. Butcher, 'Towards the History of Malayan Society: Kuala Lumpur District, 1885-1912", Journal of Southeast Asia Studies, 19(2), 1988, p. 107.

${ }^{4}$ J.M. Gullick, Old Kuala Lumpur, Kuala Lumpur: Oxford University Press, 1994, p. 8.

${ }^{5}$ J.M. Gullick, A History of Kuala Lumpur, 1857-1939, MBRAS Monograph No. 29, 2000, p. 71.

${ }^{6}$ J.M. Gullick, The Story Early of Kuala Lumpur, Singapore: Donald More, 1956, p. 71.

${ }^{7}$ Selangor - State of Public Works and Survey Department, CO273/114 (10025), pp 232-237.

${ }^{8}$ D.D. Daly, 'Surveys and Exploration in the Native States of the Malayan Peninsula 1875-1882', Proceedings of the Royal Geographical Society, 1882, pp. 393-412.

${ }^{9}$ James J. Jackson, 'Kuala Lumpur in the 1880s: The Contribution of Bloomfield Douglas', Journal of Southeast Asian Studies, 4(2), 1963, pp. 123-127.

${ }^{10}$ J.M. Gullick, A History of Kuala Lumpur, 1857-1939, MBRAS Monograph No. 29, 2000, p. 96.

${ }^{11}$ Ibid., p. 97.

${ }^{12}$ The water for the town of Kuala Lumpur was collected from jungle streams from forest catchment areas especially protected as waterworks reserves. See The Selangor Journal, Vol. 2, 1893, p. 42.

${ }^{13}$ Protected Malay States, CO273/189 (15115), 1892.

${ }^{14}$ Selangor Secretariat File 72/1890, Report on a scheme for Waterworks for Kuala Lumpur.

${ }^{15}$ J.M. Gullick, A History of Kuala Lumpur, 1857-1939, MBRAS Monograph No. 29, 2000.

${ }^{16}$ Ahmad Kamal Ariffin, Sanitary Board Kuala Lumpur: The Role and Its Administration, 1890-1914, Dissertation (M.A.), Kuala Lumpur: Department of History, University of Malaya, 1994.

${ }^{17}$ Chai Hon Chan, The Development of British Malaya, 1896-1909, Kuala Lumpur: Oxford University Press, 1967.

${ }^{18}$ Selangor Secretariat File 4571/1892, Kuala Lumpur Water Supply.

${ }^{19}$ Selangor Secretariat File 246/94, Extra Works required at the Water Works.

${ }^{20}$ Selangor Secretariat File 4244/1894, Kuala Lumpur Water Works.

${ }^{21}$ Annual Report of the State of Selangor for the Year 1894, CO439/1, p. 144.

${ }^{22}$ Selangor Secretariat File 2002/1896, Annual Report of Hydraulic Engineer on the Kuala Lumpur Waterworks in 1895.

${ }^{23}$ Selangor Secretariat File 841/1896, Water Works Kuala Lumpur. Progress Report for Quarter Ending $1^{\text {st }}$ January 1896.

${ }^{24}$ Selangor Secretariat File 1493/1898, Annual Report 1897, Sanitary Board Kuala Lumpur, Engineer's Department, p. 18.

${ }^{25}$ Ibid.

${ }^{26}$ Selangor Secretariat File 3881/1897, Defective Piping for Waterworks.

${ }^{27}$ Ibid.

${ }^{28}$ Ibid.

${ }^{29}$ Federated Malay States, Selangor Administration Report for the Year 1908, CO439/3, p. 71.

${ }^{30}$ Proceedings of the Federal Council of Federated Malay States, 1911, CO576/8, p. 30.

${ }^{31}$ Selangor Administration Report for the Year 1900, CO439/2, p. 159.

${ }^{32}$ Selangor Secretariat File 3546/1901, Bonus to J. O' Hara, Chief Inspector of Kuala Lumpur Waterworks for laying on installation from Sydney Lake to Service Reservoir.

${ }^{33}$ Selangor Secretariat File 2359/1901, Scarcity of water in Kuala Lumpur Impounding Reservoir and using of the Sydney Lake Water. Special provision of $\$ 25,500$.

${ }^{34}$ Selangor Administration Report for the Year 1901, CO439/2, p. 218.

${ }^{35}$ Selangor Administration Report for the Year 1902, CO439/2, p. 277.

${ }^{36}$ Selangor Secretariat File 5336/1907, Preparation of plans for the Kuala Lumpur Water Works Extension.

${ }^{37}$ Selangor Secretariat File 2317/1906, Extension of Kuala Lumpur Water Supply 1907. 
${ }^{38}$ Selangor Secretariat File 5112/1907, Report in connection with Mr. Peirce Report on Kuala Lumpur Water Supply.

${ }^{39}$ Ibid.

${ }^{40}$ Selangor Secretariat File 2317/1906, Extension of Kuala Lumpur Water Supply 1907.

${ }^{41}$ Selangor Secretariat File 963/1907, Proposed Kuala Lumpur Water Supply Extension.

${ }^{42}$ Selangor Secretariat File 5759/1913, Preliminary Surveys - Additional Water Supply in Kuala Lumpur. Contract with Mr. J.E. Bach.

${ }^{43}$ Federated Malay States, Public Works Department, Annual Report for the Year 1923, CO576/26, p. 243.

${ }^{44}$ Annual Report on the Social and Economic Progress of the People of Selangor for the Year 1939, CO439/3, p. 801.

${ }^{45}$ Selangor Secretariat File 1355/1922, Renewing nine-inch steel impounding reservoir, Kuala Lumpur.

${ }^{46}$ Selangor Secretariat File 1356/1922, Water Works and supplies Kuala Lumpur $\$ 607,000$.

${ }^{47}$ Federated Malay States, Annual Report on the Public Works Department for the Year 1928, CO576/36, p. 440.

${ }^{48}$ Federated Malay States, Annual Report on the Public Works Department for the Year 1929, CO576/39, p. 23.

${ }^{49}$ Federated Malay States, Annual Report on the Public Works Department for the Year 1930, CO576/41, p. 574.

${ }^{50}$ H.C. Paxon, "Some Notes on Kuala Lumpur Water Supply", Selangor Journal, Vol. 2, 1894, pp. 4245.

${ }^{51}$ Annual Report on the Social and Economic Progress of the People of Selangor for the Year 1939, CO439/3, p. 801.

${ }^{52}$ This regulation was established under the administration of the State of Selangor since 1889. See Selangor Secretariat File 2900A/1889.

${ }^{53}$ Selangor Government Gazette (SGG). $15^{\text {th }}$ February 1909.

${ }^{54}$ Ibid., p. 338.

${ }^{55}$ Ibid., p. 339.

${ }^{56}$ Selangor Secretariat File 813/1914, Memorandum by Chairman of Sanitary Board regarding Charges For Private Water Supplies Under Enactment No. 3 of 1909.

${ }^{57}$ The first clause stated that to any person who damaged to waterworks such as reservoir, pump, well, pipe, lock, cock, valve, water-pipe, meter or other waterworks under the management of the State Engineer would be punished. The second clause applied to any person who flushes, draw off, divert or takes water from any waterworks under control of the State Engineer without permission. The third clause applied who bath in any waters and streams and the last clause applied who polluted the water supply for drinking purposes. Refer to Selangor Secretariat File 2599/1924, Draft of Water Supply Enactment, 1924, pp. 11-13.

${ }^{58}$ Selangor Secretariat File 688/1905, Waste of Water at Government Quarters.

${ }^{59}$ Federated Malay States, Selangor Administration Report for The Year 1914, CO439/3, p. 275.

${ }^{60}$ Selangor Secretariat File 4172/1915, Bathing in the Impounding Reservoir - Report against Mr. Johnson and others.

${ }^{61}$ Federated Malay States, Selangor Administration Report for The Year 1926, CO439/3, p. 28.

${ }^{62}$ Selangor Secretariat File 2599/1924, Draft of Water Supply Enactment, 1924.

${ }^{63}$ Selangor Secretariat File 448/1926, Proposal for a form of contract under the Waterworks Enactment of 1909 between the Sanitary Board and proprietors of ice factories to enable the Board to have some measure of control of the price of ice.

${ }^{64}$ Selangor Secretariat File 3302/1917, Amendment of Waterworks Enactment of 1909. Introduction of the system of changing by tap instead of by meter.

${ }^{65}$ Selangor Secretariat File 4276/1926, Waste of Water by Occupants of Government Quarters at Imbi Road.

${ }^{66}$ Selangor Secretariat File 2239/1917, Substitution of a fixed charge per tap instead of meter for domestic water supply in Kuala Lumpur.

${ }^{67}$ Selangor Secretariat File 813/1914, Memorandum by Chairman of Sanitary Board regarding Charges For Private Water Supplies Under Enactment No. 3 of 1909.

${ }^{68}$ Selangor Secretariat File 1786/1931, Bill to repeal and re-enact the Water Supply Enactment of 1926. 
${ }^{69}$ Federated Malay States, Selangor Administration Report for The Year 1908, CO576/3, p. 68.

${ }^{70}$ Selangor Secretariat File 813/1905, Annual Report for 1904, Sanitary Board Kuala Lumpur.

${ }^{71}$ Selangor Secretariat File 1102/1906, Sanitary Board Kuala Lumpur. Annual Report For The Year 1906.

${ }^{72}$ Federated Malay States, Selangor Administration Report For The Year 1910, CO439/3, p. 142.

${ }^{73}$ Selangor Secretariat File 762/1921, Annual Report 1920, Sanitary Board Kuala Lumpur.

${ }^{74}$ Federated Malay States, Selangor Administration Report For The Year 1910, CO439/3, p. 142.

${ }^{75}$ Selangor Secretariat File 762/1921, Annual Report 1920, Sanitary Board Kuala Lumpur.

${ }^{76}$ Selangor Secretariat File 3666/1916, Annual Report by the Chairman of the Sanitary Board Kuala Lumpur For 1915.

${ }^{77}$ Selangor Secretariat File 748/1932, Annual Report for 1931, Sanitary Board Kuala Lumpur.

${ }^{78}$ Federated Malay States, Annual Report on the Social and Economic Progress of the People of Selangor for the Year 1931, CO439/3, p. 203. 